\title{
Promotion of Innovative Entrepreneurship Under Sustainable Development
}

\author{
Tatyana Odinokova ${ }^{1}$, Mariyana Bozhinova $^{2}$, Mariana Petrova $^{3 *}$ \\ ${ }^{1}$ ISMA University, Riga, Latvia; PhD student at the D. A. Tsenov Academy of Economics, Svishtov, \\ Bulgaria \\ ${ }^{2}$ D. A. Tsenov Academy of Economics, Svishtov, Bulgaria \\ ${ }^{3}$ St. Cyril and St. Methodius University of Veliko Tarnovo, Bulgaria
}

\begin{abstract}
The subject matter of this article is incentives for innovations in entrepreneurship. There are two models of entrepreneurship which exist in developed market economies - traditional and innovative. Innovations have never been so important as they are now, which holds particularly true for small and medium-sized businesses. As Peter F.Drucker formulated it, "Innovation is the specific tool of entrepreneurs, the means by which they exploit change as an opportunity for a different business or a different service." The methods by which innovations are encouraged change from country to country. The choice of such methods depends on economic, political and other conditions for a country's development. By encouraging innovative activities, governments enhance the effectiveness of innovative systems and create favorable conditions for enterprises to engage in science and technology. For the EU, which falls behind the USA and Japan in so far as innovation technologies are concerned, it is a highpriority task to implement the innovation development strategy and to transform its economy in accordance with the up-to-date model by 2020 . The aim of such strategy is to achieve industrial leadership as well as to support business, including small and medium-sized businesses.
\end{abstract}

\section{Introduction}

Nowadays, innovative entrepreneurship plays a key role in a nation's economic development. Economic literature identifies two models of entrepreneurship - a conventional and an innovative one. The first model suggests entrepreneurship of a traditional type where the entrepreneur aims to manage their business with a view to get the highest possible return on the resources. It is widely thought that the concept of production growth management is formed within the framework of the traditional model, while production growth management itself relies on external factors, such as funding or protectionism by the government. At the same time, internal reserves of an enterprise

* Corresponding author: m.petrova@uni-vt.bg 
intended to modernize production, increase profitability and renew the product range, are put in motion.

\section{Ways to Promote Innovative Entrepreneurship}

Innovative entrepreneurship suggests a specific type of commercial activity intended to make profit by creating innovations and proactively marketing them in the national economy. As opposed to the traditional entrepreneurship, the innovative one relies on looking for new ways to develop an existing enterprise. Such innovation could involve new products, technologies, markets, materials, or setting up a pioneering enterprise [1].

The innovation process of the 21 st century is radically different to that of the preceding one. Perhaps the most important difference is the new or renewed importance of new and small firms. The change can be resumed as a shift from the "Managed Economy" to the "Entrepreneurial Economy" [2,3]. In the former, science and systematic large firm R\&D was the key. In the latter, entrepreneurship is one of the foundations of innovation.

The reason why new and small businesses have become key players in the innovation process has been their ability to identify and exploit business opportunities which emerge as a result of technological, competitive and market developments.

Besides, large scale economy in $R \& D$ is no longer an obstacle for small and medium size enterprises, as was the case in the past. Nowadays, innovations are normally carried out in collaboration between universities, research organizations, customers, suppliers, business rivals and consumers. Such tendency makes it possible to share both the expenses and the tasks. Concurrently, there has been a massive transition from production to services, which has led to the emergence of new kinds of non-technological innovation in which small and medium size enterprises may play a key role.

Throughout the last decade, the EU has been involved in the formation of innovative policies at three levels, namely, regional, interregional and transnational. The current EU development strategy "Europe 2020" has adopted five priority targets intended to increase the employment rate of the population, to implement innovation, to improve the quality of education, to reduce the risk of poverty and social exclusion and to tackle the problems related to climate change and the shortage of energy and other resources. In order to meet these targets, a framework programme called "Horizon 2020" was launched on 1 January, 2014. There are three priority areas that form the basis for Horizon 2020, namely: (a) generating an advanced expertise to reinforce Europe's competitiveness among the leading global nations; (b) industrial leadership and political backing of businesses including small and medium size businesses and innovation; (c) tackling social problems to meet the challenges of the contemporary world which were specified in the "Europe 2020" strategy. These tasks involve the accomplishment of all the stages of the innovative chain, from research outcome to its commercialization and marketing. That said, not only technological, but also social innovations are considered [4].

In order to support economically backward economies and regions of Europe, European programme is planning to provide $€ 80 \mathrm{~m}$, or $25 \%$ of the total EU structural funds, in regional development funds. In 2020, expenses on research and innovation will increase to $8.5 \%$ in the total EU budget, compared to $6.7 \%$ in $2013[5,6]$.

Creation of start-up businesses as well as implementing innovation in the existing small and medium size businesses is the key element of the present day innovation process. It should be the primary focus of the government's strategy to promote innovation. However, backing of entrepreneurship and small and medium size businesses in particular has not so far been incorporated in the innovation policy. Moreover, requirements for an effective 
policy in this field are still not quite clear. Start-ups and innovative small and medium size businesses tend to be considered as agents of change in economy, since they implement new products and services as well as more effective practices. They help to adapt our economies and communities to new challenges and spur economic development.

According to European Innovation Scoreboard (EIS), in 2016 Latvia was found the most dynamic innovator among the EU countries. It had a $4 \%$ growth of the effectiveness of innovation, which was enough to be upgraded to the group of Moderate Innovators. That said, effectiveness of innovation in Latvia is only $54 \%$ of the European average [7]

The latest statistic data have shown that $28.2 \%$ of industrial enterprises and $23.4 \%$ of service providing enterprises are active innovators. That said, funding of research and development in Latvia was reduced in 2016. Indeed, R\&D expenses amounted to $0.62 \%$ of the GDP, while in 2016 this figure dropped to $0.44 \%$ [8]. There were a number of changes in the sources of R\&D funding in 2016 (Figure 1).

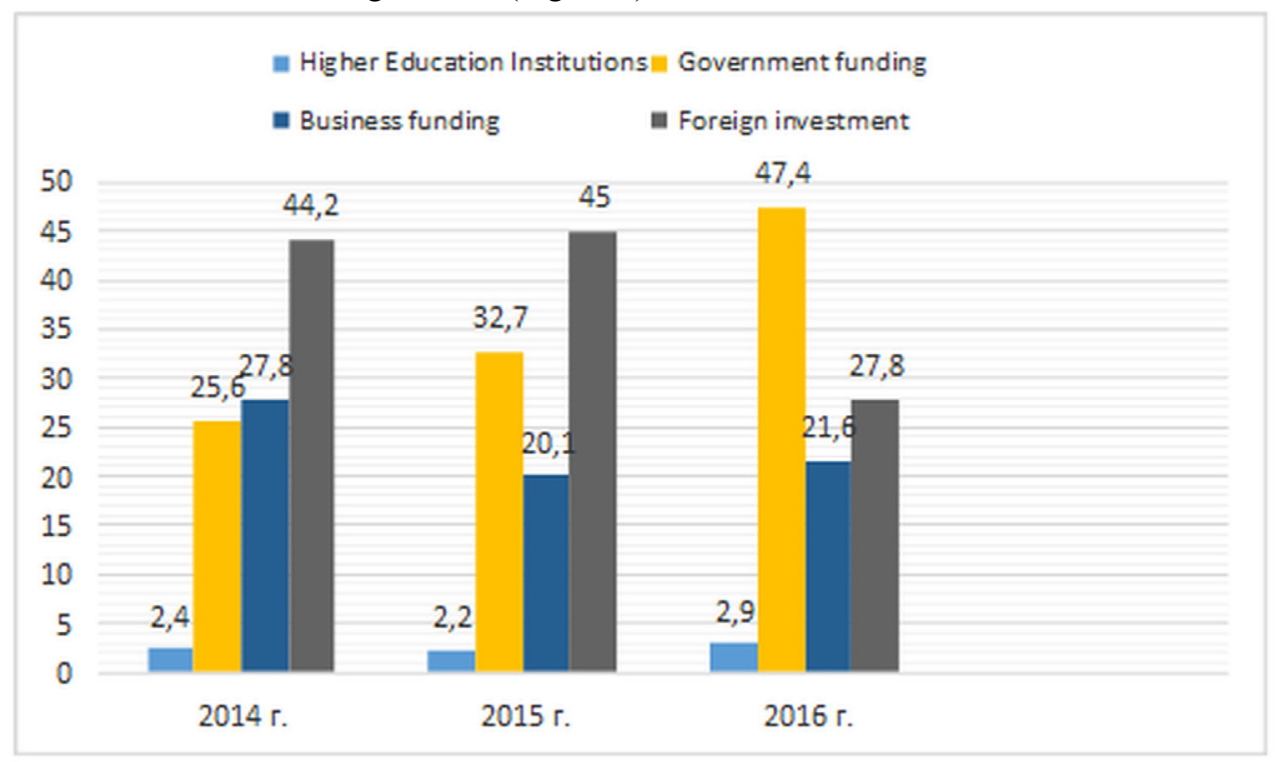

Fig. 1. Sources of R\&D Funding in Latvia (\%) [8].

The share of government spending rose significantly from $25.6 \%$ in 2014 to $47.4 \%$ in 2016, which can be considered as the evidence of direct promotion of innovative enterprises. At the same time, the share of foreign investment fell from $44.2 \%$ in 2014 to $27.8 \%$ in 2016, while the share of funding by private business $-21.6 \%$ in 2016 as opposed to $27.8 \%$ in 2014 . Insignificant as the drop may appear, it could imply a pessimistic opinion of the business community about the prospects of Latvia's economic development.

But to achieve it is necessary to increase funding, for example in general, for EU (28 countries) R\&D expenditure share in GDP increased by 16,67 \% from 2005 [9].

Enterprises' innovative activities, small and medium size enterprises in particular, rely on the forms and methods of promotion. Industrially developed economies have accumulated vast experience in applying direct and indirect methods to promote innovative activity. Direct methods of promoting innovative activity include: government funding of projects by providing grants, vouchers, subsidies, as well as by means of venture investment, soft loans and state procurement. Indirect methods aim to secure private 
investment to the innovative activity. Indirect methods of promoting innovation include: creation of industrial clusters, business incubators and tax exemptions [10,11].

Business communities shall recognize that companies' ability to implement innovations can be a powerful trigger to competitive advantage and process effectiveness, which are so important for small companies which have the understanding that research and development expenses are investments into future development. Methodical basis for this may be the procedure for determining the value of intellectual property [9].

The methods of direct and indirect promotion of innovative activity in Latvia have been developed on the basis of international expertise and with consideration of the specific challenges of the national economy. Consolidated information is represented in Table 1.

Information presented in Table 1 shows that all the methods that are typical of the majority of the EU countries are applied in Latvia. However, Latvia lags behind the other countries in so far as innovative activity is concerned. In 2017, Latvia only ranked 33rd, while its close neighbor Estonia ranked 25th [12].

Creation of technology parks could be used as an example to illustrate this situation. Latvian Technology Centre (LTC) was set up as far back as 1993. Originally, it was intended to develop innovative and technologically oriented entities to support small and medium sized businesses in Latvia. Today however, the number of technology parks in Latvia is quite insignificant compared to the EU member states. An example would be the number of technology parks in the Nordic countries - 30 parks in Sweden, 22 in Finland and 12 in Norway [13]

Research has shown that overall growth of innovative activity has been mostly due to technological innovations, whereas such activity in the field of marketing and management has been a lot lower. Such disproportion is particularly visible in big entities, while in small companies it is less common.

According to the Programme for improvement of the National Innovation System, the methods of promoting innovative activity in Latvia have had little effect for the following reasons [14].

Table 1. Methods to promote innovative activities in Latvia [Sources 15, 16].

\begin{tabular}{|l|l|}
\hline Direct promotion & Aims \\
\hline $\begin{array}{l}\text { Investment in industrial } \\
\text { infrastructure and facilities }\end{array}$ & $\begin{array}{l}\text { Construction, reconstruction or renovation of industrial } \\
\text { facilities to be used by small and medium size enterprises in } \\
\text { the manufacturing and processing industry. }\end{array}$ \\
\hline $\begin{array}{l}\text { Direct funding (innovation } \\
\text { vouchers) }\end{array}$ & $\begin{array}{l}\text { Intended for small and medium size enterprises involved in } \\
\text { the development of new products and technologies. }\end{array}$ \\
\hline Indirect promotion & Aims \\
\hline Centers of competence & $\begin{array}{l}\text { Support of R\&D and innovative activity (elaboration of new } \\
\text { products and technologies) based on specific industrial needs. }\end{array}$ \\
\hline $\begin{array}{l}\text { Transfer of technology } \\
\text { programmes }\end{array}$ & $\begin{array}{l}\text { Increase in the earnings of scientific entities due to } \\
\text { commercialization of their research funded by the } \\
\text { government, assistance in marketing the results of such } \\
\text { research by converting it into practical entrepreneurship. }\end{array}$ \\
\hline $\begin{array}{l}\text { Support of innovative } \\
\text { product implementation }\end{array}$ & $\begin{array}{l}\text { Measures to facilitate the increase of efficiency and } \\
\text { competitive edge of enterprises by implementing new } \\
\text { products and technologies and by increasing private } \\
\text { investment in R\&D. }\end{array}$ \\
\hline
\end{tabular}




\begin{tabular}{|c|c|}
\hline $\begin{array}{l}\text { Innovation motivation } \\
\text { programme }\end{array}$ & $\begin{array}{l}\text { Provision of publicity and stimulating the public, young } \\
\text { people in particular, to become entrepreneurs and to } \\
\text { participate in innovative activity. }\end{array}$ \\
\hline Staff search support & $\begin{array}{l}\text { Supplying skilled labour force to entrepreneurs to promote } \\
\text { higher efficiency as well as development and implementation } \\
\text { of new products and technologies. }\end{array}$ \\
\hline Competitive edge globally & Support of participation in international fairs and exhibitions. \\
\hline Business incubators & $\begin{array}{l}\text { Support of viable start-ups with high competitive ability in } \\
\text { Latvian regions by providing business environment, } \\
\text { consultancy services and access to funding. }\end{array}$ \\
\hline Clusters & $\begin{array}{l}\text { Support of export and turnover in a specific industry to } \\
\text { promote specialization and cooperation in the development of } \\
\text { new products or creation of value chain (inter-industrial } \\
\text { cooperation) }\end{array}$ \\
\hline Corporative income tax & To encourage the purchase of new technological equipment. \\
\hline
\end{tabular}

- Random nature of the streams of expertise and low performance efficiency;

- Insufficient innovative resources in Latvia (human capital, technologies, funding). Moreover such resources are not used in the most efficient way;

- Insufficient communication between the entities involved;

- Business environment does not encourage innovative processes.

In view of this, economic and socio-economic benefits seem to be insufficient to support the process, to say nothing of the advantages for the society and the national economy.

Raising innovative activity of small and medium size businesses is an objective that provides an opportunity to influence economic growth in a positive way. These companies have the advantage of a low level of organisational and maintenance costs, the ability to respond promptly to market demand, while their management proves to be dynamic and flexible. Due to these factors, small and medium sized enterprises are an efficient tool for elaboration and implementation of innovative changes.

\section{Conclusion}

Methods of promoting innovation differ from country to country. Latvian experience has shown that the choice of such methods depends on economic, political and other conditions of national development. That said, even though the range of methods for both direct and indirect promotion is wide, they do not impact the innovative characteristic of the national economy. In consideration of the foregoing premises, it can be concluded that the methodsin-use have to be analyzed, the most effective ones have to be identified and a model for promoting innovative activities has to be elaborated to meet national economic challenges.

Promotion of innovative activity in small and medium size enterprises impact economic growth in a positive way. Such businesses have a low level of organisational and maintenance costs, the ability to respond promptly to market demand, they are managed in a dynamic and flexible way. Due to these factors, small and medium sized enterprises are an efficient tool for elaboration and implementation of innovative changes.

Innovations spur the competitive edge of business environment, which makes them an essential prerequisite for national economic development, even more so under the conditions of the modern global market. In particular, enterprises should aim to use their 
resources and competitive edge to secure investment in innovation. Today, smart business, which helps enterprises to be competitive both domestically and globally, is driven by innovative business models as well as by new products, services and development processes.

\section{References}

1. V. G. Medinskiy, L. G. Skamay, Innovacionoye predprinimatelstvo (2002)

2. R. Turik, Research Paper, 12 (2009)

3. D.Audretsch, R.Thurik, International Journal of Entrepreneurship Education, 2(2), 143 (2004)

4. European Commission (Joint Research Centre. 2013)

5. E.Y. Gorbatenko Globalnoye nauchno-tehnicheskoye $i$ innovacionnoye razvitiye Evropeyskogo soyuza v ramkah programmi "Gorizont 2020” (2013)

6. O. A. Sushchenko, I. M. Trunina, D. M. Zagirniak, Modern Electrical and Energy Systems (MEES), 344 (2017)

7. European Innovation Scoreboard (2017)

8. Latvijas statistikas gadagrāmata 2017 (2018)

9. S.V. Labunska, M. Petrova, O. Prokopishyna,. Economic Annals, 165(5-6) 13 (2017)

10. OECD Science, Technology and Industry Scoreboard (2011)

11. OECD Science, Technology and Industry Scoreboard (2011)

12. Globalniy innovacionniy indeks (2017)

13. Evrostate (2017)

14. Program for improvement of the National Innovation System (2016)

15. Supporting innovations and business in Latvia State Aid Financial instruments 20142020 (2017)

16. Support Measures for Innovations and SMEs (2016)

17. O. A. Sushchenko, I. M. Actual Probl Econ 177(3) 191 (2016)

18. Kristina Balkienè, Jonas Jagminas, Viešoji politika ir administravimas, 34, 32 (2010) 